\title{
Vegetation analysis and population of tarsier (Tarsius spectrumgurskyae) at Batuputih Nature Tourism Park, North Sulawesi, Indonesia
}

\author{
ARRIJANI ${ }^{1, \boldsymbol{\varphi}}$, MUHAMMAD RIZKI ${ }^{2}$ \\ ${ }^{1}$ Department of Biology Faculty of Mathematics and Natural Sciences, Universitas Negeri Manado. Jl. Kampus Unima, Kelurahan Tonsaru, Tondano \\ Selatan, Minahasa 95618, North Sulawesi, Indonesia. Tel.: +62-431-321845, Fax.: +62-431-321866, `email: arrijani@ unima.ac.id \\ ${ }^{2}$ Department of Biology, Faculty of Mathematics and Natural Sciences, Universitas Palangka Raya. Palangka Raya 73111, Central Kalimantan, Indonesia
}

Manuscript received: 29 October 2019. Revision accepted: 15 January 2020.

\begin{abstract}
Arrijani, Rizki M. 2019. Vegetation analysis and population of tarsier (Tarsius spectrumgurskyae) at Batuputih Nature Tourism Park, North Sulawesi, Indonesia. Biodiversitas 20: 530-537. Tangkasi or Tarsius (Tarsius spectrumgurskyae) is a world's smallest primate, which categorized as an endemic and protected species inhabited Sulawesi Island. Batuputih Nature Tourism Park (Batuputih NTP) at Tangkoko Batuangus Nature Reserve, Bitung City, North Sulawesi, Indonesia is one of the habitats of the primate. The research aimed to characterize the habitats of Tarsius that include physical and vegetation characteristics and to figuring out the nest distribution and estimation of the population of this species. The vegetation data were sampled using a quadrat sampling technique around Tarsius nests. The Tarsius population was estimated along a $2 \mathrm{~km}$ transect line with the distance $50 \mathrm{~m}$ to the left and right across the line (the total width $100 \mathrm{~m}(0.1 \mathrm{~km})$. Meanwhile, to calculate population abundance (Overall estimate of population size/abundance) can be obtained by multiplying population densities with the total area of all observations. The result revealed that the vegetation types of Tarsius habitats were dominated by tree species which associated with Liana from the family Araliaceae, among them include Spathodea campanulata, Ailanthus integrifolia, Kleinhovia hospital, Alstonia scholaris, Garuga floribunda, Arenga pinnata, and two sleeping trees without accosiated from the species of Ficus tinctoria and Ficus variegata. Tarsius life in groups with 2-8 individuals per group. The estimation of population density was found that there were 270 individuals $/ \mathrm{km}$ or 2.7 individuals/ha and their total abundance around 1660 individuals of Tarsius lived in Batuputih NTP.
\end{abstract}

Keywords: Batuputih NTP, habitat characteristics, population, Tarsius

\section{INTRODUCTION}

Tarsius is a genus of the smallest primates in the world, and the members live in several islands in Indonesia, such as Sulawesi, Kalimantan, and Sumatra, also in the Philippines (Sussman 1999). These primates are endemic throughout the northern tip of Sulawesi in the Sangihe Islands to the southern tip of Sulawesi in the Selayar Islands. Local people call them by various names such as tangkasi, monkey ghosts, and small monkeys, while in the international world know them as Tarsius sp. This genus comes from the family of Tarsiidae, the only family that survived from the order Tarsiiformes. Tarsius has a crepuscular nature (active at dusk or dark situations) and nocturnal and is very active throughout the night (GurskyDoyen and Supriatna 2010).

Tarsius is protected under Indonesian Law No. 5/1990 and Government Regulation No. 7/1999; and according to IUCN (2008), Tarsius listed in the IUCN Red Data Book in the category of vulnerable. Recently released publications stated that two new Tarsius species were found in Sulawesi. One of them was named Tarsius spectrumgurskyae, which replaces the Tarsius Manado form according to the results of the latest genetic studies. The name was given to honor a scientist who has dedicated and played a pivotal role in conservation efforts in Indonesia. He is Dr. Sharon Gursky who has studied Tarsius in the Tangkoko conservation area, Bitung, North
Sulawesi for more than 20 years and made him the worldfamous Tarsius expert (Shekelle et al. 2017).

Tarsius are frequently captured from wild because of their uniqueness, possibly for exotic pet and public consumption. These hunting activities together with habitat loss due to shifting cultivation, development, mining, and logging, present a serious threat to the existence of this species. Therefore, conservation efforts addressing the presence of Tarsius in nature are critical. Such efforts, like researches on ecological aspects of their population and habitat characteristics, not only will save the Tarsius population in nature but also, it would directly link to maintaining a sustainable source of biodiversity.

Tarsius can be found in lowland forest, Batuputih Nature Tourism Park in Batuputih Village, Bitung City, North Sulawesi, hereinafter referred to as Batuputih NTP. The habitat that Tarsiers favor is tropical rain forests which have abundant water sources that support their food. They can also be found in secondary forests, mostly in small and medium trees (Yasuma and Alikodra 1990) tropical rain forests that have an abundant water source that supports their food. They also can be found in secondary forests, mostly in small and medium-sized trees (Yasuma and Alikodra 1990).

Sulawesi's forests have experienced a dramatic loss of native forest (Whitten et al. 2001) and a decline in primate population density (Gursky, 1998a; ), so the quality of habitat plays a critical role in wildlife conservation 
(Merker, 2006). A good habitat quality will support all activities of the Tarsius, including reproductive behavior so that it can live normally (Qiptiyah and Setiawan 2012).

The availability of food sources from the surrounding is one of the factors supporting the conservation of primates in the wild. In addition, the feed also influences the wide home range associated with primate movement behavior in addition to efforts to fulfill energy sources for growth and breeding (Bismark 2009).

Batuputih Nature Tourism Park, Bitung City, is part of the Tangkoko Batuangus Nature Reserve, which is managed by the North Sulawesi Natural Resources Conservation Agency, Indonesia. Batuputih NTP ecotourism offers several advantages, one of which is the ease access to flagship species such as yaki and Tarsius (Shekelle and Leksono 2004), Also, in Batuputih NTP there are camping ground and many lodgings outside the area. But, apart from its beneficial advantages, Batuputih NTP should be driven as a useful tool for conservation education that needs to be artificially divided by zones so that visitors coming to Batuputih NTP can be controlled. It is clearly understood that ecotourism is not a panacea for preserving biodiversity. There is no ecologically neutral tourism, and there will always be an impact.

Research concerning the ecological status and population of Tarsius in the Batuputih NTP remains unexplored. Considering the situation of this area as a tourist park, where human activity is complicated to avoid, it is critically important to initiate the research of their population and habitat characteristics.

\section{MATERIALS AND METHODS}

\section{Study site}

The study was conducted for three months in the Batuputih Nature Tourism Park (Batuputih NTP), part of Tangkoko Batuangus Nature Reserve, that geographically located at 0130'-0134 'N and 12514'39 "-12506'46" E, and included in Batuputih Village, North Bitung Sub-district, Bitung City, North Sulawesi Province, Indonesia. Batuputih NTP situated at an altitude between 0-200 $\mathrm{m}$ asl. with a gentle, flat, and slightly hilly field toward the border of the nature reserve area. The flat area is in the coastal, which covers $40 \%$ of the area. Climatic conditions in Batuputih NTP based on Schmidt and Ferguson classification type B climate with annual average rainfall around $2,279 \mathrm{~mm}$ and daily average temperatures of 23$24^{\circ} \mathrm{C}$. The vegetation is dominated by coastal forest vegetation and secondary forest vegetation such as: bitung (Barringtonia asiatica), ketapang (Terminalia catappa), waru (Hibiscus tiliaceus), sea kale (Ipomoea pescaprae), pandan (Pandanus tectorius), gora forest (Eugenia spp.), egg wood (Alstonia scholaris), and red banyan (Ficus benjamina) (WCS 2000).

\section{Vegetation analysis}

Vegetation analysis in the Tarsius habitat was performed by the quadratic method (Mueller-Dumbois and Ellenberg 1974; Kusmana 1997). Determination of area and the minimum number of plots used a relieve method and species-area curve. Ropes and measuring tape were used to make the plots. Each plot was placed around the Tarsius habitat especially its sleeping habitat. the characters of their sleeping tree were observed.

The physical characteristics of the Tarsius habitat were determined by observing and measuring the parameters as follows: (i) Altitude. Measurement of the altitude at the study site was carried out using Garmin Etrex 10. (ii) Temperature and humidity. Daily air temperature and humidity were measured using a dry-wet thermometer. Measurement of temperature and humidity is carried out between 05.30-06.00 WITA.

\section{Tarsius population}

Tarsius population was sampling and estimated using a line transect method (Kurniawan 2009). This method is often used in collecting data on the types and numbers of individual wildlife. The length and width of the path are adjusted to the topographic conditions and stand density at the observation site. Data collected is based on direct counting with the primates shown along the sampling track (Kurniawan 2009).

In secondary forests, a transect line was made along a 2 $\mathrm{km}$ forest trail. The data recorded is the number of individuals or groups of Tarsius based on direct or indirect observation (voice) while the number of individuals in one group is determined by assuming that in each group there are at least two individual Tarsius (Merker 2006).

\section{Distribution}

The geographic distribution of Tarsius estimated according to the location of their sleeping tree, is done by marking the area that becomes the nest of the Tarsius using Garmin Etrex 10 and then analyzed using ArcMap GIS 10.1 software.

\section{Habitat characteristics \\ Physical components}

The physical components of the Tarsius habitat being analyzed consist of altitude, temperature and humidity, and distance from the settlement. All the components were analyzed descriptively from the results of identification, observation, and measurement as well as the actual conditions in the field.

\section{Analysis of vegetation}

Vegetation data collected from the field is used to calculate the frequency, density, dominance and important value index of a plant species. These values can be expressed in the form of absolute values and relative values with the following equation:

$$
\begin{aligned}
& \text { Density (D) }=\frac{\text { Number individual of species }}{\text { total plot area }} \\
& \text { Relative Density (RD) }=\frac{\text { Density of a species }}{\text { Total density of all species }}
\end{aligned}
$$


Frequency $(\mathrm{F})=\frac{\text { total number of plots species presented }}{\text { Total number of plots studied }}$
Relative Frequency $(\mathrm{RF})=\frac{\text { The frequency of a species }}{\text { Frequency of all species }}$
Domination (D) $=\frac{\text { Number of Basal area }}{\text { total plot area }}$
Relative Domination $(\mathrm{RD})=\frac{\text { Domination of a species }}{\text { Dominationn af all speceis }}$
Important Value index $=\mathrm{RD}+\mathrm{RF}+\mathrm{RD}$ (trees and poles)
Important Value index $=\mathrm{RD}+\mathrm{RF}$ (stage and seedling)
Basal area of-i $=\frac{1}{4} \cdot \pi \cdot d_{i}^{2}$

The diversity and evenness of plant species in the population, the equation is used:

$$
\begin{aligned}
& H^{\prime}=-\sum_{i=1}^{s}\left(\frac{n i}{N}\right)\left(\ln \frac{n i}{N}\right) \\
& E=H^{\prime} / \log S
\end{aligned}
$$

Where: $H^{\prime}=$ Species diversity index Shannon-Wiener, $\mathrm{ni}=$ number of individual or species important value of the i-th, $\mathrm{N}=$ Total of the individual or total important value, $\mathrm{S}$ $=$ Number of species (Southwood and Henderson 2000).

The similarity vegetation in the community was calculated by the Index of Similarity (IS) with the following equation:

$$
\text { IS }=\frac{2 w}{a+b} \times 100 \%
$$

Where: IS = Similarity index of community, $\mathrm{W}=$ the number of the same value and the lowest value of species common to both the forest stands, $\mathrm{a}=$ the number of quantitative values for all species presented in the first stand, $b=$ number of quantitative values for all species presented in the 2 nd stand.

\section{Nest characteristics}

After analyzing the vegetation around the Tarsius nest, a descriptive analysis was also carried out on the plant species that were thought of as the Tarsius's sleeping sites. A binocular device was used to facilitate observation of the trees.

\section{Tarsius population}

Estimation of the population using a transect method, where the length of the transect line (To-T1 distance $=2$ $\mathrm{km}$ ), the width of the transect by cutting contours, $50 \mathrm{~m}$ left and $50 \mathrm{~m}$ right $=100 \mathrm{~m}(0.1 \mathrm{~km})$. So the area of the lane = $2 \mathrm{~km} \times 0.1 \mathrm{~km}=0.2 \mathrm{~km} 2$. Meanwhile, to calculate population abundance (Overall estimate of population size/abundance) can be obtained by multiplying population densities with the total area of all observations (Kyes et al. 2010).

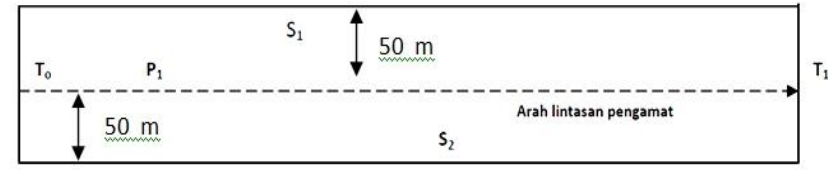

Where: $\mathrm{T}_{0}=$ starting point of transect line, $\mathrm{T}_{1}=$ endpoint of transect line, $\mathrm{P}=$ position of observer, $\mathrm{S}=$ position of wildlife

\section{Distribution}

Tarsius distribution data based on their sleeping location that has been marked on GPS, then analyzed using ArcMap GIS 10.1 software.

\section{RESULTS AND DISCUSSION}

\section{Habitat characteristics}

Vegetation analysis was performed at each location of the Tarsius sleeping tree at Batuputih NTP of Tangkoko Batuangus Nature Reserve. The minimum plot size to be used in this study was $20 \mathrm{~m}$ x $20 \mathrm{~m}$ for trees, $10 \times 10 \mathrm{~m}$ for poles and $5 \times 5 \mathrm{~m}$ for stakes. The placement of sample plots is based on Tarsius nests (sleeping trees). A total of 21 randomized plots are placed on the research track along the $2 \mathrm{Km}$ line transect path. The placement and number of plots considered the presence of the Tarsius nest and terrain traversed. Then all calculations on density, relative density, relative frequency, dominance, relative dominance, and important value index are in Table 1, 2, 3 and 4. The data shows the composition and structure of plants whose value varies in each type due to differences in the character of each tree. According to Kimmins (1987), variations in the structure and composition of plants in a community are influenced, among others, by plant phenology, dispersal, and natality.

Several types of plants around the sleeping habitats of Tarsius that have the highest IVI from the level of stakes is Barringtonia acutangula (21.12); poles is Morinda bracteate (45.31); and trees is Spathodea campanulate (66.62) respectively. This means, ecologically, the composition of these species shows characteristics of the habitat.

Plants have important roles in the daily activities of the Tarsius. During its movement, the Tarsius needs a branch with a small diameter $(<4 \mathrm{~cm})$ mainly for hunting and exploring, medium diameter $(4-8 \mathrm{~cm})$ for resting and marking the home range, while diameter $>8 \mathrm{~cm}$ is also used for resting and marking home range although not as much as moderate diameter (MacKinnon and MacKinnon 1980). Aside from being a means of mobilization, the presence of various types of plants also plays a critical role in creating microclimates for the life of insects and insects are the main feed source of Tarsius.

The important value index can be used for calculating the Shannon-Wiener diversity index $\left(H^{\prime}\right)$ (formula $\left.3 a\right)$. The results show that the species diversity index in all the plots being studied was 3.31. Based on the category by Barbour et al. (1987), the species diversity index of 3.31 is included in the medium category. The diversity index value 
illustrates the richness of tree species in the Batuputih NTP area. Because only 21 plots were scattered in determining the diversity index, the value of species diversity at the research location was actually higher than the results reported in this study. Therefore the level of vegetation biodiversity at the research location is actually very high.
This condition illustrates that the ecosystem in Tangkoko Batuputih is actually a stable ecosystem and has approached a climax. This conclusion is supported by the fact that the species that dominate almost the entire research area are some typical tree species with relatively uniform strata.

Table 1. IVI Value of tree species on a 20 x 20 m plot found in Batuputih NTP, Bitung City, North Sulawesi, Indonesia

\begin{tabular}{|c|c|c|c|c|c|c|c|}
\hline Species name & KM & KR & FM & FR & DM & DR & INP \\
\hline Spathodea campanulata & 57 & 12.2137 & 57.14 & 5.714286 & 2621424.87 & 48.69088 & 66.62 \\
\hline Morinda citrifolia & 64 & 13.7404 & 85.71 & 8.571429 & 570993.163 & 10.60574 & 32.92 \\
\hline Arenga pinnata & 40 & 8.65135 & 28.57 & 2.857143 & 1079105.79 & 20.04353 & 31.55 \\
\hline Barringtonia acutangula & 22 & 4.83458 & 66.67 & 6.666667 & 39542.4628 & 0.73447 & 12.24 \\
\hline Kleinhovia hospital & 19 & 4.07122 & 42.86 & 4.285714 & 184219.459 & 3.42173 & 11.78 \\
\hline Cocos nucifera & 14 & 3.05342 & 47.62 & 4.761905 & 108535.098 & 2.015953 & 9.83 \\
\hline Alstonia scholaris & 11 & 2.54451 & 47.62 & 4.761905 & 68785.2468 & 1.277631 & 8.58 \\
\hline Morinda bracteata & 17 & 3.81677 & 38.1 & 3.809524 & 19497.9041 & 0.362158 & 7.98 \\
\hline Dracontamelon dao & 14 & 3.05342 & 28.57 & 2.857143 & 108535.098 & 2.015953 & 7.92 \\
\hline Macaranga sp. & 13 & 2.79897 & 42.86 & 4.285714 & 36597.8828 & 0.679777 & 7.76 \\
\hline Caryota mitis & 17 & 3.81677 & 33.33 & 3.333333 & 28118.4315 & 0.522277 & 7.67 \\
\hline Garuga floribunda & 4 & 1.01781 & 19.05 & 1.904762 & 181114.971 & 3.364066 & 6.28 \\
\hline Alstonia sumatrana & 11 & 2.54451 & 19.05 & 1.904762 & 49689.302 & 0.922939 & 5.37 \\
\hline Homalium celebicum & 17 & 3.81677 & 9.524 & 0.952381 & 28421.593 & 0.527908 & 5.29 \\
\hline Eugenia sp 2 & 10 & 2.29006 & 23.81 & 2.380952 & 17624.5462 & 0.327362 & 4.99 \\
\hline Cananga odorata & 10 & 2.29006 & 23.81 & 2.380952 & 6930.61571 & 0.128731 & 4.8 \\
\hline Palaquium obovatum & 7 & 1.52671 & 28.57 & 2.857143 & 9058.5357 & 0.168255 & 4.55 \\
\hline Polyscias nodosa & 7 & 1.52671 & 28.57 & 2.857143 & 3956.58439 & 0.07349 & 4.45 \\
\hline Piper aduncum & 7 & 1.52671 & 23.81 & 2.380952 & 26922.0409 & 0.500055 & 4.40 \\
\hline Crateva nurlava & 8 & 1.78116 & 19.05 & 1.904762 & 18651.2765 & 0.346433 & 4.03 \\
\hline Melanolepis multiglandulosa & 7 & 1.52671 & 19.05 & 1.904762 & 2984.76712 & 0.05544 & 3.48 \\
\hline Canarium asperum & 3 & 0.76335 & 14.29 & 1.428571 & 58077.7176 & 1.078747 & 3.27 \\
\hline Koordersiodendron pinnatum & 5 & 1.27226 & 19.05 & 1.904762 & 2471.40393 & 0.045904 & 3.22 \\
\hline Clerodendrum minahassae & 4 & 1.01781 & 19.05 & 1.904762 & 1594.01539 & 0.029608 & 2.95 \\
\hline Eugenia sp 1 & 4 & 1.01781 & 14.29 & 1.428571 & 10642.2671 & 0.197672 & 2.64 \\
\hline Ailanthus integrifolia & 7 & 1.52671 & 9.524 & 0.952381 & 7129.30202 & 0.132421 & 2.61 \\
\hline Artocarpus dadah & 4 & 1.01781 & 14.29 & 1.428571 & 6400.76699 & 0.118889 & 2.56 \\
\hline Albizia saponaria & 4 & 1.01781 & 14.29 & 1.428571 & 2656.5824 & 0.049344 & 2.49 \\
\hline Ficus tinctoria & 4 & 1.01781 & 9.524 & 0.952381 & 25619.5568 & 0.475863 & 2.44 \\
\hline Ficus variegata & 2 & 0.5089 & 9.524 & 0.952381 & 30697.4549 & 0.570181 & 2.03 \\
\hline Pisonia umbellifera & 3 & 0.76335 & 9.524 & 0.952381 & 3335.0345 & 0.061946 & 1.77 \\
\hline Tectona grandis & 3 & 0.76335 & 9.524 & 0.952381 & 2862.21404 & 0.053163 & 1.76 \\
\hline Pongamia pinnata & 3 & 0.76335 & 9.524 & 0.952381 & 438.541003 & 0.008146 & 1.72 \\
\hline Vittex quinata & 2 & 0.5089 & 9.524 & 0.952381 & 10958.1316 & 0.203539 & 1.66 \\
\hline Pterospermum celebicum & 2 & 0.5089 & 9.524 & 0.952381 & 703.888004 & 0.013074 & 1.47 \\
\hline Sterculia comosa & 2 & 0.5089 & 9.524 & 0.952381 & 614.015393 & 0.011405 & 1.47 \\
\hline Cryptocarya bicolor & 2 & 0.5089 & 9.524 & 0.952381 & 586.252654 & 0.010889 & 1.47 \\
\hline Ardisia myristicaefolia & 2 & 0.5089 & 9.524 & 0.952381 & 246.07285 & 0.004571 & 1.46 \\
\hline Diospyros pilosanthera & 2 & 0.5089 & 9.524 & 0.952381 & 240.448514 & 0.004466 & 1.46 \\
\hline Pterospermum diversifolium & 1 & 0.25445 & 4.762 & 0.47619 & 3636.06754 & 0.067537 & 0.79 \\
\hline Ficus sp 1 & 1 & 0.25445 & 4.762 & 0.47619 & 1506.80003 & 0.027988 & 0.75 \\
\hline Ficus septica & 1 & 0.25445 & 4.762 & 0.47619 & 926.966561 & 0.017218 & 0.74 \\
\hline Ceiba pentandra & 1 & 0.25445 & 4.762 & 0.47619 & 517.309581 & 0.009609 & 0.74 \\
\hline Cordia myxa & 1 & 0.25445 & 4.762 & 0.47619 & 457.072718 & 0.00849 & 0.73 \\
\hline Memecylon sp & 1 & 0.25445 & 4.762 & 0.47619 & 363.322718 & 0.006748 & 0.73 \\
\hline Cassia fistula & 1 & 0.25445 & 4.762 & 0.47619 & 141.003848 & 0.002619 & 0.73 \\
\hline Eugenia littorale & 1 & 0.25445 & 4.762 & 0.47619 & 72.2531847 & 0.001342 & 0.73 \\
\hline Mangifera kweni & 1 & 0.25445 & 4.762 & 0.47619 & 68.3658439 & 0.00127 & 0.73 \\
\hline Buchanania arborescens & 1 & 0.25445 & 4.762 & 0.47619 & 60.5122081 & 0.001124 & 0.73 \\
\hline Garcinia sp. & 1 & 0.25445 & 4.762 & 0.47619 & 39.5010616 & 0.000734 & 0.73 \\
\hline Gnetum gnemon & 1 & 0.25445 & 4.762 & 0.47619 & 38.8561571 & 0.000722 & 0.73 \\
\hline Amount & 467 & 100 & 1000 & 100 & 5383811.34 & 100 & 300 \\
\hline
\end{tabular}

Note: $\mathrm{KM}=$ absolute density, $\mathrm{KR}=$ relative density, $\mathrm{FM}=$ absolute frequency, $\mathrm{FR}=$ relative frequency, $\mathrm{DM}=$ absolute dominance, $\mathrm{DR}$ $=$ relative dominance, $\mathrm{INP}=$ important value index 
Table 2. IVI Value of Poles species on a $10 \times 10 \mathrm{~m}$ plot found in Batuputih NTP, Bitung City, North Sulawesi, Indonesia

\begin{tabular}{|c|c|c|c|c|c|c|c|}
\hline Species name & KM & KR & FM & FR & DM & DR & INP \\
\hline Morinda bracteata & 57 & 10.5042 & 95.238 & 9.3462 & 54487.72 & 25.45977 & 45.31 \\
\hline Barringtonia acutangula & 57 & 10.5042 & 71.429 & 7.0097 & 40602.276 & 18.9717 & 36.48 \\
\hline Eugenia sp.2 & 55 & 10.0665 & 52.381 & 5.1404 & 31468.612 & 14.70393 & 29.91 \\
\hline Palaquium obovatum & 41 & 7.87815 & 71.429 & 7.0097 & 21584.001 & 10.08527 & 24.97 \\
\hline Spathodea campanulata & 39 & 7.22164 & 52.381 & 5.1404 & 20371.262 & 9.518614 & 21.88 \\
\hline Canarium asperum & 29 & 5.47094 & 42.857 & 4.2058 & 9291.7434 & 4.341632 & 14.02 \\
\hline Clerodendrum minahassae & 20 & 3.72024 & 57.143 & 5.6077 & 4849.7157 & 2.266063 & 11.59 \\
\hline Ailanthus integrifolia & 23 & 4.37675 & 38.095 & 3.7385 & 7251.6265 & 3.388373 & 11.50 \\
\hline Gnetum gnemon & 23 & 4.37675 & 38.095 & 3.7385 & 6211.7076 & 2.902464 & 11.02 \\
\hline Melanolepis multiglandulosa & 13 & 2.40721 & 42.857 & 4.2058 & 2144.0097 & 1.001803 & 7.61 \\
\hline Canarium asperum & 14 & 2.62605 & 19.048 & 1.8692 & 2781.287 & 1.299576 & 5.79 \\
\hline Mahangbahu* & 14 & 2.62605 & 14.286 & 1.4019 & 2605.5543 & 1.217463 & 5.24 \\
\hline Alstonia scholaris & 9 & 1.7507 & 28.571 & 2.8039 & 1017.3036 & 0.475342 & 5.03 \\
\hline Morinda citrifolia & 14 & 2.62605 & 9.5238 & 0.9346 & 2172.6153 & 1.01517 & 4.57 \\
\hline Koodersiodendron pinnatum & 7 & 1.31303 & 23.81 & 2.3366 & 560.5105 & 0.261902 & 3.91 \\
\hline Pongamia pinnata & 9 & 1.7507 & 14.286 & 1.4019 & 652.96103 & 0.305101 & 3.45 \\
\hline Maranthes corymbosa & 7 & 1.31303 & 19.048 & 1.8692 & 480.49742 & 0.224516 & 3.41 \\
\hline Glochidion philippicum & 5 & 1.09419 & 19.048 & 1.8692 & 415.38141 & 0.19409 & 3.16 \\
\hline Dracontamelon dao & 5 & 1.09419 & 19.048 & 1.8692 & 318.85047 & 0.148985 & 3.11 \\
\hline Pterospermum celebicum & 7 & 1.31303 & 14.286 & 1.4019 & 697.75933 & 0.326033 & 3.04 \\
\hline Terminalia catappa & 4 & 0.87535 & 19.048 & 1.8692 & 307.95041 & 0.143892 & 2.88 \\
\hline Crateva nurlava & 4 & 0.87535 & 19.048 & 1.8692 & 232.24238 & 0.108517 & 2.85 \\
\hline Diospyros maritime & 5 & 1.09419 & 14.286 & 1.4019 & 519.03245 & 0.242522 & 2.74 \\
\hline Arenga pinnata & 5 & 1.09419 & 14.286 & 1.4019 & 340.08284 & 0.158906 & 2.65 \\
\hline Leea indica & 7 & 1.31303 & 9.5238 & 0.9346 & 803.98942 & 0.37567 & 2.62 \\
\hline Polyscias nodosa & 3 & 0.65651 & 14.286 & 1.4019 & 187.69431 & 0.087701 & 2.15 \\
\hline Vittex quinata & 3 & 0.65651 & 14.286 & 1.4019 & 107.00637 & 0.049999 & 2.11 \\
\hline Homalium celebicum & 4 & 0.87535 & 9.5238 & 0.9346 & 181.00641 & 0.084577 & 1.89 \\
\hline Sterculia comosa & 3 & 0.65651 & 9.5238 & 0.9346 & 247.49867 & 0.115645 & 1.71 \\
\hline Buchanania arborescens & 3 & 0.65651 & 9.5238 & 0.9346 & 101.97149 & 0.047647 & 1.62 \\
\hline Piper aduncum & 2 & 0.43768 & 9.5238 & 0.9346 & 107.00637 & 0.049999 & 1.42 \\
\hline Szysigium littorale & 2 & 0.43768 & 9.5238 & 0.9346 & 98.886298 & 0.046205 & 1.42 \\
\hline Caryota mitis & 2 & 0.43768 & 9.5238 & 0.9346 & 89.332158 & 0.041741 & 1.41 \\
\hline Garuga floribunda & 2 & 0.43768 & 9.5238 & 0.9346 & 84.737072 & 0.039594 & 1.41 \\
\hline Polyalthia glauca & 2 & 0.43768 & 9.5238 & 0.9346 & 75.910866 & 0.03547 & 1.41 \\
\hline Mangifera sp. & 2 & 0.43768 & 9.5238 & 0.9346 & 67.064756 & 0.031336 & 1.40 \\
\hline Dendrognide microstigma & 2 & 0.43768 & 9.5238 & 0.9346 & 48.411435 & 0.022621 & 1.39 \\
\hline Mallotus columnaris & 2 & 0.43768 & 9.5238 & 0.9346 & 47.134706 & 0.022024 & 1.39 \\
\hline Cryptocarya bicolor & 2 & 0.43768 & 9.5238 & 0.9346 & 46.293032 & 0.021631 & 1.39 \\
\hline Saraca sp. & 3 & 0.65651 & 4.7619 & 0.4673 & 100.73173 & 0.047068 & 1.17 \\
\hline Eugenia sp.1 & 2 & 0.43768 & 4.7619 & 0.4673 & 44.632431 & 0.020855 & 0.93 \\
\hline Diospyros hebecarpa & 1 & 0.21884 & 4.7619 & 0.4673 & 63.091447 & 0.02948 & 0.72 \\
\hline Ficus tinctoria & 1 & 0.21884 & 4.7619 & 0.4673 & 36.041288 & 0.016841 & 0.70 \\
\hline Buru-buru* & 1 & 0.21884 & 4.7619 & 0.4673 & 21.898696 & 0.010232 & 0.69 \\
\hline Mata Ikan* & 1 & 0.21884 & 4.7619 & 0.4673 & 16.515014 & 0.007717 & 0.69 \\
\hline Garcinia tetrandra & 1 & 0.21884 & 4.7619 & 0.4673 & 15.287572 & 0.007143 & 0.69 \\
\hline Macaranga sp. & 1 & 0.21884 & 4.7619 & 0.4673 & 12.974864 & 0.006063 & 0.69 \\
\hline Garcinia sp. & 1 & 0.21884 & 4.7619 & 0.4673 & 12.53507 & 0.005857 & 0.69 \\
\hline Alstonia sumatrana & 1 & 0.21884 & 4.7619 & 0.4673 & 11.889597 & 0.005555 & 0.69 \\
\hline Kleinhovia hospital & 1 & 0.21884 & 4.7619 & 0.4673 & 10.449841 & 0.004883 & 0.69 \\
\hline Ardicia rumphii & 1 & 0.21884 & 4.7619 & 0.4673 & 10.449841 & 0.004883 & 0.69 \\
\hline Amount & 544 & 100 & 1019 & 100 & 214015.14 & 100 & 300 \\
\hline
\end{tabular}

The evenness value of species in the community is then determined based on the value of the species diversity index. The result showed that the evenness value $(\mathrm{E})$ is 1.27 (formula $3 b$.) Which means that the similarity of species in the community is high. The evenness value of species is determined by the distribution of each species in each plot equally. The more evenly distributed a species in all research sites, the higher the evenness value. And vice versa if certain species are dominant while other types are not dominant or have a lower density, then the value of evenness of the community will be lower. If in a community, there are one or several dominant tree species, 
the value of evenness of the trees in the community concerned will be lower than that of communities that are not dominated by certain tree species (Arrijani 2008).

The results also revealed that Tarsius inhabited secondary forest areas and Saccharum spontaneum grasslands. In this study, 19 Tarsius families were found, in which two families lived in dense bushes from $\mathrm{S}$. spontaneum grass. A similar finding was also stated by MacKinnon and MacKinnon (1980) that Tarsius in the
Tangkoko Batuangus Nature Reserve forest could be in very diverse sleeping locations. These locations include in dense bushes of $S$. spontaneum grass or tangling of vines or epiphytic ferns, in cracks or holes in the tree with more than one opening (Figure 2). As stated by Gursky (1998) and Wirdateti-Dahruddin (2006) that the Ficus species is often used as a sleeping tree in CA Tangkoko (Tarsius Figure 3).

Table 3. IVI Value of Stakes species on a 5 x 5 m plot found in Batuputih NTP, Bitung City, North Sulawesi, Indonesia

\begin{tabular}{|c|c|c|c|c|c|c|c|}
\hline Species name & $\mathbf{K M}$ & $\mathbf{K R}$ & FM & FR & $\mathbf{D M}$ & DR & INP \\
\hline Barringtonia acutangula & 66 & 14.77 & 57.14286 & 6.349206 & 54.15908 & 12.74092 & 21.125 \\
\hline Palaquium obovatum & 35 & 7.91 & 100 & 11.11111 & 36.64316 & 8.620297 & 19.027 \\
\hline Eugenia sp.2 & 48 & 10.81 & 71.42857 & 7.936508 & 44.79451 & 10.5379 & 18.754 \\
\hline Morinda bracteata & 33 & 7.38 & 80.95238 & 8.994709 & 33.38262 & 7.853256 & 16.383 \\
\hline Ailanthus integrifolia & 44 & 9.76 & 28.57143 & 3.174603 & 42.57658 & 10.01613 & 12.937 \\
\hline Spathodea campanulata & 15 & 3.43 & 57.14286 & 6.349206 & 16.98514 & 3.995751 & 9.7793 \\
\hline Melanolepis multiglandulosa & 17 & 3.95 & 33.33333 & 3.703704 & 16.85244 & 3.964534 & 7.6615 \\
\hline Saraca sp. & 19 & 4.22 & 19.04762 & 2.116402 & 17.09888 & 4.022508 & 6.338 \\
\hline Mangifera sp. & 13 & 2.90 & 28.57143 & 3.174603 & 12.05641 & 2.83627 & 6.077 \\
\hline Diospyros cauliflora & 11 & 2.63 & 23.80952 & 2.645503 & 11.92372 & 2.805053 & 5.284 \\
\hline Clerodendrum minahassae & 11 & 2.63 & 19.04762 & 2.116402 & 13.06112 & 3.072625 & 4.7549 \\
\hline Pterospermum celebicum & 7 & 1.58 & 28.57143 & 3.174603 & 7.336215 & 1.725843 & 4.7577 \\
\hline Dracontamelon dao & 5 & 1.31 & 28.57143 & 3.174603 & 1.137398 & 0.267573 & 4.4939 \\
\hline Pongamia pinnata & 8 & 1.84 & 19.04762 & 2.116402 & 7.791174 & 1.832872 & 3.9634 \\
\hline Eugenia sp.1 & 9 & 2.11 & 14.28571 & 1.587302 & 8.454656 & 1.988956 & 3.6981 \\
\hline Cananga odorata & 7 & 1.58 & 19.04762 & 2.116402 & 6.274644 & 1.476109 & 3.6995 \\
\hline Koordersiodendron pinnatum & 5 & 1.31 & 19.04762 & 2.116402 & 5.213072 & 1.226374 & 3.4357 \\
\hline Gnetum gnemon & 7 & 1.58 & 14.28571 & 1.587302 & 7.108735 & 1.672329 & 3.1704 \\
\hline Kleinhovia hospita & 4 & 1.05 & 19.04762 & 2.116402 & 5.023506 & 1.181779 & 3.1718 \\
\hline Mata ikan* & 5 & 1.31 & 14.28571 & 1.587302 & 6.388383 & 1.502866 & 2.9066 \\
\hline Morinda citrifolia & 7 & 1.58 & 9.52381 & 1.058201 & 6.938126 & 1.632193 & 2.6413 \\
\hline Vittex quinata & 3 & 0.79 & 14.28571 & 1.587302 & 3.31741 & 0.78042 & 2.3789 \\
\hline Sterculia comosa & 3 & 0.79 & 14.28571 & 1.587302 & 3.20367 & 0.753663 & 2.3789 \\
\hline Leea indica & 4 & 1.05 & 9.52381 & 1.058201 & 4.473764 & 1.052452 & 2.1136 \\
\hline Crateva nurlava & 3 & 0.79 & 9.52381 & 1.058201 & 3.506976 & 0.825016 & 1.8498 \\
\hline Diospyros maritima & 4 & 1.05 & 4.761905 & 0.529101 & 4.189415 & 0.985559 & 1.5845 \\
\hline Polyalthia glauca & 2 & 0.52 & 9.52381 & 1.058201 & 6.028207 & 1.418135 & 1.5859 \\
\hline Piper aduncum & 2 & 0.52 & 9.52381 & 1.058201 & 2.217925 & 0.521767 & 1.5859 \\
\hline Alstonia scholaris & 3 & 0.79 & 4.761905 & 0.529101 & 3.108887 & 0.731365 & 1.3207 \\
\hline Ficus septica & 1 & 0.26 & 4.761905 & 0.529101 & 1.63027 & 0.383521 & 0.793 \\
\hline Buchanania arborescens & 1 & 0.26 & 4.761905 & 0.529101 & 1.535487 & 0.361223 & 0.793 \\
\hline Maranthes corymbosa & 1 & 0.26 & 4.761905 & 0.529101 & 1.289051 & 0.303249 & 0.793 \\
\hline Horsfieldia brachiata & 1 & 0.26 & 4.761905 & 0.529101 & 1.270094 & 0.298789 & 0.793 \\
\hline Glochidion philippicum & 1 & 0.26 & 4.761905 & 0.529101 & 1.232181 & 0.28987 & 0.793 \\
\hline Polyscias nodosa & 1 & 0.26 & 4.761905 & 0.529101 & 1.232181 & 0.28987 & 0.793 \\
\hline Planchonia valida & 1 & 0.26 & 4.761905 & 0.529101 & 1.118441 & 0.263113 & 0.793 \\
\hline Macaranga $\mathrm{sp}$ & 1 & 0.26 & 4.761905 & 0.529101 & 1.080528 & 0.254194 & 0.793 \\
\hline Alstonia sumatrana & 1 & 0.26 & 4.761905 & 0.529101 & 1.080528 & 0.254194 & 0.793 \\
\hline Mallotus columnaris & 1 & 0.26 & 4.761905 & 0.529101 & 1.080528 & 0.254194 & 0.793 \\
\hline Cryptocrya bicolor & 1 & 0.26 & 4.761905 & 0.529101 & 1.061571 & 0.249734 & 0.793 \\
\hline Garcinia sp. & 1 & 0.26 & 4.761905 & 0.529101 & 0.985745 & 0.231896 & 0.793 \\
\hline Calophyllum soulattri & 1 & 0.26 & 4.761905 & 0.529101 & 0.985745 & 0.231896 & 0.793 \\
\hline Amount & 451 & 100 & 900 & 100 & 425.0834 & 100 & 200 \\
\hline
\end{tabular}

Note: $\mathrm{KM}=$ absolute density, $\mathrm{KR}=$ relative density, $\mathrm{FM}=$ absolute frequency, $\mathrm{FR}=$ relative frequency, $\mathrm{DM}=$ absolute dominance, DR $=$ relative dominance, $\mathrm{INP}=$ important value index. $*$ ) Local name (unidentified) 
Table 4. Importing Value Index in Batuputih NTP, Bitung City, North Sulawesi, Indonesia

\begin{tabular}{lllcc}
\hline Level Local name & \multicolumn{1}{c}{ Species name } & $\begin{array}{c}\text { Density } \\
\text { (ind/ha) }\end{array}$ & IVI (\%) \\
\hline Stakes & Salense & Barringtonia acutangula & 66 & 21.12 \\
Poles & Mengkudu & Morinda bracteata & 57 & 45.31 \\
Trees & Kayu bunga & Spathodea campanulata & 57 & 66.62 \\
\hline
\end{tabular}

Furthermore, 17 other Tarsius families live in secondary forests and they inhabit trees and poles with a height of 1-17 m from ground level. Their sleeping trees include Spathodea campanulata, Ailanthus integrifolia, Kleinhovia hospital, Alstonia scholaris, Arenga pinnata, Terminalia catappa, Garuga floribunda, Ficus tinctoria, and Ficus variegata. All of these trees exclude $F$. variegata (dead plant), F. tinctoria (hollow tree) and Arenga pinnata are associated with liana forming a grove of sleeping trees as in Figure 2. The temperature of the habitat of the sleeping tree around $24^{\circ} \mathrm{C}-27^{\circ} \mathrm{C}$ with humidity $81 \%$ up to $99 \%$.

\section{Estimation of population abundance}

During the study, Tarsius were found in various locations along the transect line at altitudes ranging from 9$46 \mathrm{~m}$ asl. The results showed that in one family constitute two to six individuals could be found. The estimated population density of Tarsius is 270 per $\mathrm{km}^{2}$ or 2.7 individuals per ha with a total of 1660 individuals found in the Tangkuputih Tangkoko Nature Park. Shekelle and Salim (2008), said the population of Tarsius, primates living in the forests of Sulawesi declined dramatically in the last ten years. It is estimated that the number of Tarsius in the Batuputih NTP in North Sulawesi, only 1,800 individuals remains. In fact, in 1998, the number of Tarsius was still around 3,500 individuals. This is due to the area of
Batuputih Nature Tourism Park experiencing damage and habitat change due to forest fires, hunting, logging and making the area by local residents into agricultural land.

\section{Distribution}

Tarsius are most commonly found in secondary forests with a total of 50 individuals from 17 families compared to the number of Tarsius found in dense bushes of $S$. spontaneum grass which only has one family with three members, and two other families found around community settlements totaling four individuals (Figure 3). This is in accordance with the research of Mustari et al (2013) which states that Tarsius are generally found around secondary forests and fields with dense vegetation. This is closely related to the presence of abundant food sources in secondary forest areas compared to S. spontaneum fields.

In conclusion, the Tarsius observed in Batuputih NTP inhabited the holes situated in trees of fig ( $F$. tinctoria) and coro ( $F$. variegata); seho tree (A. pinnata) and trees associated with liana i.e. nusu (T. catappa), kayu kambing (G. floribunda), kayu telur (A. scholaris), bintangar ( $K$. hospital), kayu bunga ( $S$. campanulata) and wariu (A. integrifolia). The estimated population density of Tarsius during the research in the Batuputih NTP 270 individuals $/ \mathrm{km}^{2}$ and its total abundance reaches 1660 individuals with the largest Tarsius population is found in secondary forests.

\section{ACKNOWLEDGEMENTS}

The authors expressed special thanks to the North Sulawesi Natural Resources Conservation Center for allowing the research conducted, and especially to the staff of the Batuputih NTP, Yunus, and all guides. And thanks also to Maryati Abiduna (Tompotika Conservation Alliance) for their advice and guidance during the research.

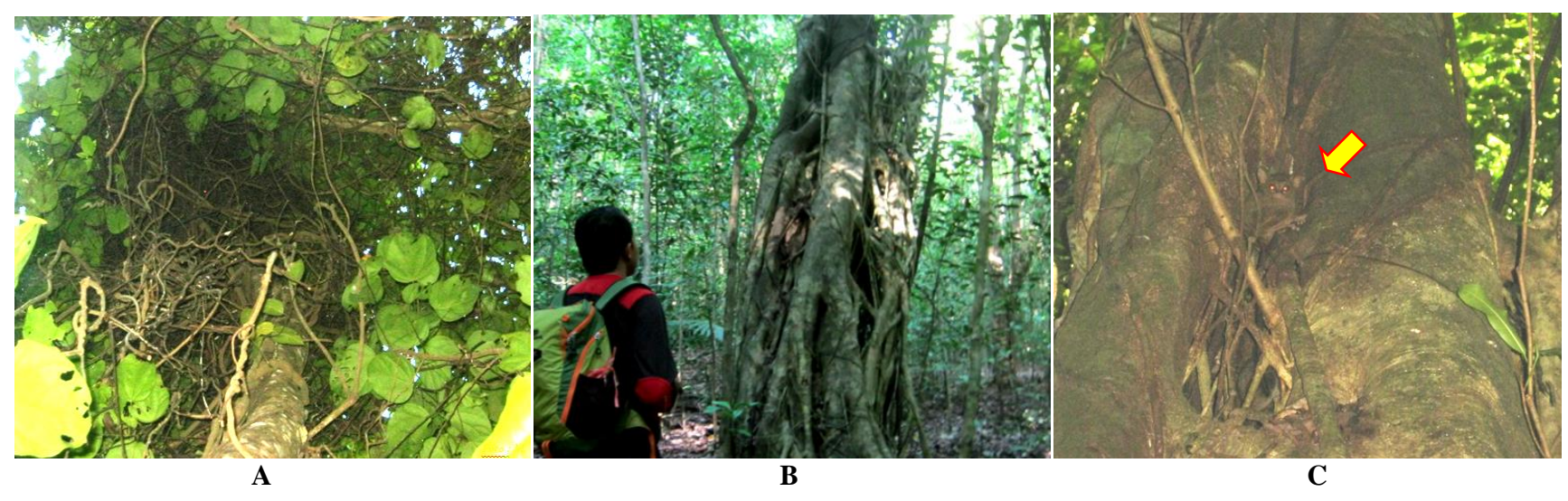

Figure 1. Tarsius as sleeping tree: A. Wariu tree (Ailanthus integrifolia), B. Ficus tree (Ficus tinctoria), C. Tarsius in ficus tree (arrow) 


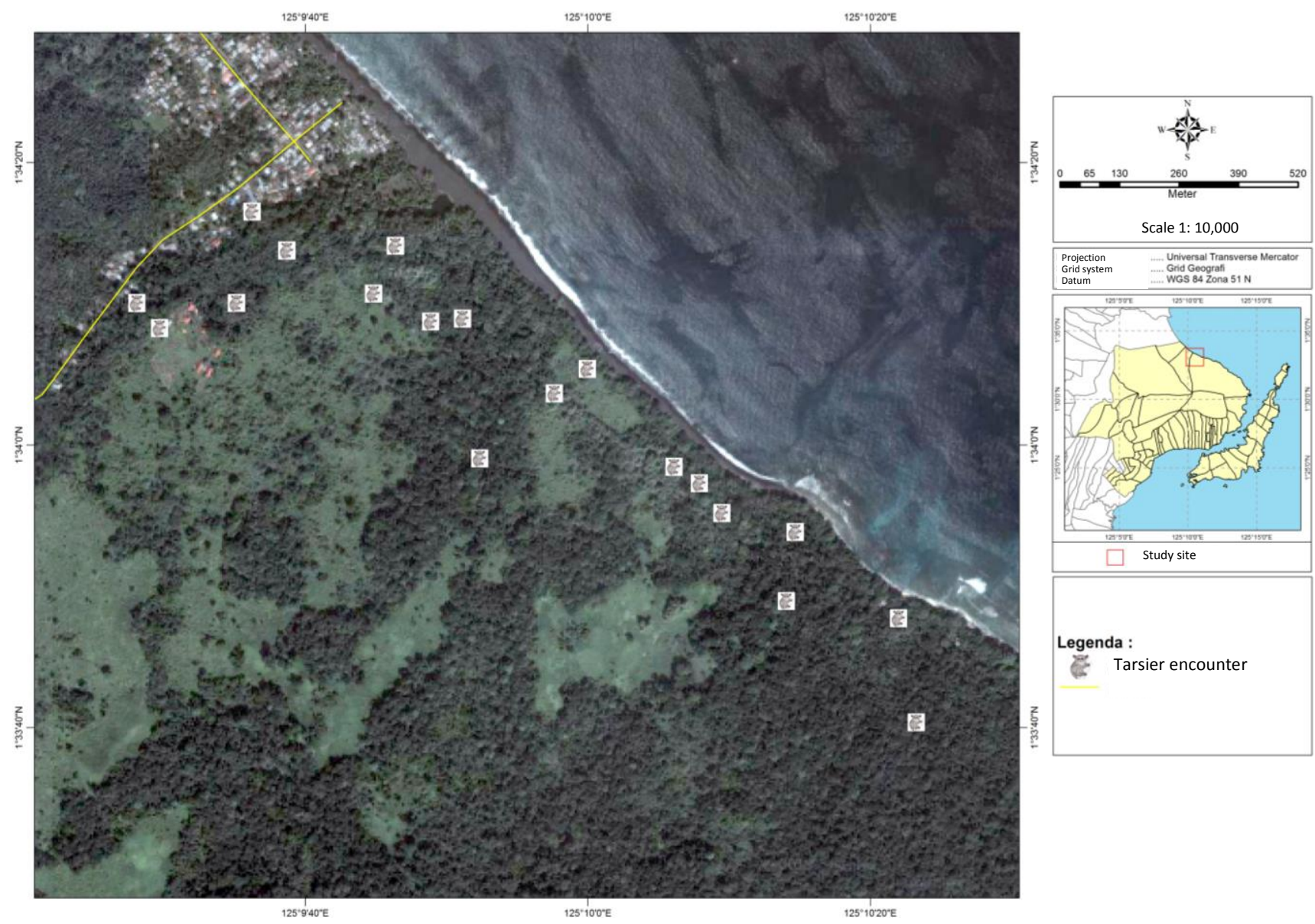

Figure 3. Distribution map of Tarsius location found in Batuputih Nature Tourism Park, Bitung City, North Sulawesi, Indonesia

\section{REFERENCES}

Barbour GM, Burk JK, Pitts WD. 1987. Terrestrial Plant Ecology. The Benyamin/Cummings Publishing Company, New York.

Bismark M. 2009. Bekantan (Nasalis larvatus) Conservation Biology. Center for Forest Research and Development and Nature Conservation, Bogor

Gursky S. 1998. Conservation status of the spectral tarsier Tarsius spectrum: population density and home range size. Folia Primatoligica 69 (1): 191-203.

Gursky-Doyen S, Supriatna J. 2010. Indonesian Primates. Springer, New York.

Kurniawan I. 2009. Mammal Inventory Method. "Tarsius" Mamma Observers Group HIMAKOVA. Institut Pertanian Bogor, Bogor.

Kusmana C. 1997. Metode Survei Vegetasi. IPB Press, Bogor [Indonesian]

Kyes R, Onibala J, Hapri L. 2010. Conservation Biology Training University of Washington, (in collaboration with Samratulag University and IPB University). Samratulangi Publishing, Manado.

MacKinnon J, MacKinnon K. 1980. The behavior of Wild Spectral Tarsiers. Intl J Primatol 1 (4): 361-379.

Merker S, Yustian I, Muhlenberg M. 2004. Losing ground but still doing well-Tarsius dianae in human-altered rainforests of central Sulawesi, Indonesia. In: Gerold G, Fremerey M, Guhardja E (eds.). Land Use, Nature Conservation and the Stability of Rainforest Margins in Southeast Asia. Springer, Heidelberg.

Merker S. 2006. Habitat-specific ranging pattern of dian's tarsier (Tarsiu dianae) as revealed by radiotracking. Am J Primatol 68 (2): 111-125.

Mueller-Dumbois D, Ellenberg H. 1974. Aims and Methods of Vegetation Ecology. John Wiley \& Sons, Toronto.
Mustari AH, Fadhilah IM, Dones R. 2013. Karakteristik habitat dan populasi Tarsius (Tarsius fuscus Fischer 1804) di Resort Balocci Taman Nasional Bantimurung Bulussaraung Sulawesi Selatan. Media Konservasi 18 (1): 47-53. [Indonesian]

Qiptiyah M, Setiawan H. 2012. Kepadatan populasi dan karakteristik habitat Tarsius (Tarsius spectrum Pallas 1779) di Kawasan Pattunuang, Taman Nasional Bantimurung Bulussaraung, Sulawesi Selatan. Jurnal Penelitian Hutan dan Konservasi Alam 9 (4): 363-371. [Indonesian]

Shekelle M, Groves CP, Maryanto I, Mittermeier RA. 2017. Two new tarsier species (Tarsiidae, Primates) and the biogeography of Sulawesi, Indonesia. Primate Conserv 31: 1-9.

Shekelle M, Mukti L. 2004. Strategi konservasi di pulau Sulawesi dengan menggunakan Tarsius sebagai flagship spesies. Biota Jurnal Ilmiah Ilmu-ilmu Hayati 9 (1): 1-10. [Indonesian]

Shekelle M, Salim A. 2008. Tarsius tarsier. The IUCN Red List of Threatened Species 2008: e.T21491A9288932. DOI: 10.2305/IUCN.UK.2008.RLTS.T21491A9288932.en. [11 August 2019].

Sussman RB. 1999. Primate Ecology and Social Structure. Vol. I.: Lorises. Lemurs and Tarsiers. Department of Anthropology, Washington University, Seattle

WCS [Wildlife Conservation Society]. 2000. Press Release: Lansekap Tangkoko-Duasudara. http://wcsip.org/content/view/59/1/lang,indonesian/. [10 July 2019]

Whitten AJ, Mustafa M, Henderson GS. 2001.The Ecology of Sulawesi. Periplus Editions, Singapore.

Wirdateti, Dahruddin H. 2006. Pengamatan pakan dan habitat Tarsius spectrum (Tarsius) di kawasan Cagar Alam Tangkoko-Batu Angus, Sulawesi Utara. Biodiversitas 7 (4): 373-377.

Yasuma S, Alikodra HS. 1990. Mammals of Bukit Soeharto Protection Forest. The Tropical Rain Research Project, Samarinda. 